\title{
IMPLEMENTATION OF INCOME TAX ON VIRTUAL OFFICE IN INDONESIA
}

\author{
Luthfi Racha Arif ${ }^{1}$ \\ Department of Fiscal Administrative Science, \\ Faculty of Administrative Science, Universitas Indonesia \\ (Email: rachaarif21@gmail.com) \\ Milla Sepliana Setyowati ${ }^{2}$ \\ Department of Fiscal Administrative Science, \\ Faculty of Administrative Science, Universitas Indonesia \\ (Email: milla.s.setyowati@gmail.com)
}

Accepted date: $28-05-2019$

Published date: 11-07-2019

To cite this document: Arif, L. R., \& Setyowati, M. S. (2019). Implementation of Income Tax in Virtual Office in Indonesia. International Journal of Law, Government and Communication, 4(15), 263-273.

DOI: $10.35631 /$ ijlgc. 4150025

\begin{abstract}
Virtual office is a service that provides rent of business addresses, receptionist services, call forwarding services, mailing services, and also provides a rent of meeting room for company usage. In terms of Income Tax Law, Virtual Office has clearly and firmly not been set. This study aims to analyze virtual office treatment for taxing purposes, that is, to be treated as a service or a rent. It also checks the imposition of Indonesian Income Tax on a virtual office. This study uses a qualitative approach with data collection through in-depth interviews and literature studies. The results of this study indicate that the virtual office fulfils the requirements of rents and services. Virtual office can be treated as a rent if there is Article 4 paragraph (2) on the rent and land building. Meanwhile, if the virtual office does not provide room usage, it can be treated as management service. The imposition of income tax on a virtual office which is considered as a service, is subject to Article 23 Income Tax on management service. How to determine the virtual office in general and the treatment in income tax.
\end{abstract}

Keywords: Virtual Office, Rent, Service, Income Tax

\section{Introduction}

Companies that want to establish a Limited Liability Company are required to have an office address as stipulated in Act Number 40 of 2007 concerning Limited Liability Companies (hereinafter referred to as the PT Law). In addition, in the case of registration of the Taxpayer Identification Number (TIN) and Taxable Entrepreneur, as well as registration of Business Domicile Certificate (BDC) and Trading Business License also require an address as a business domicile. However, for business people who do not have a permanent place of residence, renting an office or buying an office is very burdensome in terms of costs. Especially for new business people who stand with a little capital structure and do not really need an office as a 
place of business such as Micro, Small and Medium Enterprises (MSMEs) or start-up. Therefore, services appear that are willing to rent out business addresses with strategic and prestigious locations, namely virtual offices. In the case of using a virtual office, those who rent will get services to use virtual office addresses as company domiciles as well as correspondence addresses, reception services, and call forwarding services, and use of meeting rooms or business lounges in a limited time and subject to availability.

The existence of a virtual office makes it easy for small businesses with limited capital because the cost is much cheaper than the cost of renting or buying a physical office. Virtual office also gives a better company impression for its users. This is because employers can use business addresses in prestigious locations to be included in the company's domicile address and correspondence address. Therefore, often small businesses use virtual offices to register their businesses to be confirmed as Limited Liability Companies and facilitate tax administration and other administrative matters.

The user will pay the rental price or service fee to the virtual office provider that he uses. However, Law No. 36 of 2008 concerning Income Tax (hereinafter referred to as Income Tax Act) in Indonesia does not explicitly state the imposition of virtual office income tax. In Article 23 of the Income Tax Law, which is further regulated in the Regulation of the Minister of Finance Number 141 / PMK.03 / 2015 concerning Other Types of Services As intended in Article 23 Paragraph (1) Letter C Number 2 of Act Number 7 of 1983 concerning Income Taxes As The Last Amended Times Several Times With Law No. 36 of 2008 (hereinafter referred to as PMK 141 of 2015) also did not mention about virtual office services. Virtual office is also difficult if it is categorized as an object of Income Tax Article 4 paragraph (2) letter d of Income Tax Law on leasing land and / or buildings. This is because in some virtual office providers do not provide rental services to rent rooms that are dedicated to use by virtual office users. Services in a virtual office are usually for sharing room use or sharing with other virtual office users so that each room cannot be identified. For virtual offices that provide room use, the usage is limited per month and often users do not use the space because it depends on room availability.

Lack of legal certainty in the income tax treatment of the virtual office can lead to differences of opinion when going to impose income tax on the virtual office. Based on this description, the subject matter is the determination of services or leases for virtual offices and the imposition of Income Tax on virtual offices. The research questions proposed in this study are: (1) How is the determination of virtual office in terms of the concept of services and rent? (2) How to impose income tax on a virtual office?

Based on the research question, the purpose of this research is to analyze and determine the virtual office including the service or rental category. In addition, to analyze the imposition of Income Tax on a virtual office according to the Income Tax Act.

\section{Literature Review}

\section{Service}

Services can be interpreted as many meanings and some experts try to define these services. Lehtinen (1983 in Lupiyoadi, 2013) states that services are "a service is an activity or a series of activities that take place in interactions with a contact person or physical machine and which provides consumer satisfaction." Lehtinen explained that services is an activity or series of 
activities in which there is interaction with people or machines physically and gives satisfaction to consumers who use these services. Kotler (1998; 2004 in Lupiyoadi, 2013) defines services, namely:

"A service is an activity of benefits that one party can offer to another that is essentially intangible and does not result in ownership of anything. Its production may or may not be tied to a physical product."

Kotler said that services are beneficial activities offered by one party to another party, for which the activities are intangible and do not result in any ownership. Service production may be related to physical products or not (Kotler in Nasution, 2004). Another expert, Valarie A. Zethamal and Mary Jo Bitner (1996 in Lupiyoadi, 2013) also provides a definition of services, namely "service is all economic activities whose output is generally consumed at that time." it is produced, and provides added value in forms (such as convenience, amusement, comfort or health). "The definition states that services as economic activities whose end result (output) is not a physical or construction product that is generally consumed at the time of production , and given added value such as comfort, entertainment, pleasure, or health. This shows that services are enjoyed simultaneously at the time of production and there is added value for something that is not intangible.

There are several characteristics of services that are triggered by experts and the average of these four characters that are always present in the service element, namely intangibility, inseparability, perishability, and variability. The character of the service was initiated by Kotler and Keller (2009, in Piri, 2013). The first characteristic of intangibility means that it cannot be touched, felt, seen, or kissed by the sense of smell because it is different from physical products. Services are more concerned with performance than physical results (Nirwana, 2006). Consumers will have difficulty evaluating services before buying or using the service. This character shows that basically it is not an item but an activity or activity, and that activity is intangible (Lupiyoadi, 2013)

The second characteristic is inseparability. This character shows that there is a moment of truth which is usually represented in the form of direct contact. Consumers are usually present when services are generated so that there is interaction (Kotler and Keller, 2009, in Piri, 2013). But this can be reduced if communicating by telephone, letter or invoice. Contact between consumers and service providers can create strong commitment and trust. This can be exemplified as a salesperson who entertains lunch clients or managers who meet buyers while attending a meeting (Lupiyoadi, 2013). Inseparability character also shows that production and consumption cannot be separated. Both of these occur at the same time, as doctors cannot provide services if there are no patients. This character also shows that services cannot provide physical ownership. Finally is that inseparability shows that services are difficult to distribute. The third character is perishability (easily damaged or not durable) which means that the capacity of services that are not used at one time cannot be stored for future use (Lupiyoadi, 2013). This is because service utilization occurs when customers need it (Nirwana, 2006) as the previous character states that service production and consumption occur at the same time.

The next character is variability (varies) or Lupiyoadi calls it heterogeneity, which means that the services provided are people based, causing variation in service quality (Lupiyoadi, 2013). The point is that services depend on who gives them, when, and where they are given (Kotler and Keller, 2009, in Piri, 2013). Therefore, often service marketers adjust supply to the specific needs of consumers (Lupiyoadi, 2013). 


\section{Lease}

Subekti (1995) provides a definition of leasing as an agreement between one party which binds itself to provide enjoyment of an item, for a certain time with the payment of a price by the other party and the payment of the agreement. Another definition is also mentioned by Wiryono Projodikoro (1981), namely the rent of goods is a delivery of goods to another person by the owner of the item, to start and collect the proceeds from the goods on condition of payment of rent to the owner by the user.

Yahya Harahap (1991) defines leasing as briefly as an agreement between the leasing party and the tenant. The owner of the goods will hand over the goods to the tenant so that they can be fully enjoyed by the tenant. The goods submitted do not mean giving ownership rights but only for their usefulness. The tenant as a party who enjoys the usefulness of the goods must pay the agreed rental amount.

Subekti (2005) states that leasing is a concessional agreement, which means that it is legal and binding if it has been agreed to agree on the principal elements of the lease, namely goods and prices. In addition to goods and prices, the time to rent is also one of the elements in a lease. Therefore, there are at least some elements in the lease based on Subekti's writing in his book entitled Various Agreements, namely:

- Self-binding parties, which consist of parties who rent goods and renters.

- Goods. A lease leases the goods to be enjoyed by the other party and not give up the ownership rights to the item. Goods in rent are only for use, their usefulness is enjoyed (Subekti, 1995). Goods in this case are narrow sense of things. Objects are anything that can be exploited or used as property. The term object has a very broad scope, in which there are terms of goods and rights. Objects have a broad sense because they are abstract in nature which include tangible and intangible objects. While goods are narrower meanings because they are concrete and tangible that can be seen and touched (Hasbullah, 2002). Hofmann and De Berger said that what can be an object in the lease agreement is a bodied item (lichamelijke zaken), which is bodied in this case the same as tangible objects (Hasbullah, 2002).

- Price. Submission of goods to be enjoyed by other parties is accompanied by an obligation to pay "rental price". In a lease, the rental price does not have to be in the form of money but can be in the form of goods or services (Subekti, 1995).

- Certain time. The enjoyment of the item lasts for a certain period of time.

\section{Research Methods}

\section{Data Collection Technique}

This research is a qualitative research so that the collected data is usually in the form of words and images (Neuman, 2014, p. 14). Therefore, a certain technique needs to be done so that the required data can be collected so that it helps researchers to analyze a problem. Data collection techniques used in this research are qualitative data collection techniques, with primary data sources coming from field research through in-depth interviews. In addition, secondary data was obtained through library research through a number of literatures. 


\section{Data Analysis Technique}

The results of the research data are then analyzed to be compiled and interpreted so that a research conclusion can be made. Sugiyono (2012, p. 206)suggests that data analysis is an activity after data from all respondents is collected. This study uses qualitative data analysis techniques. Qualitative data analysis techniques according to Bogdan and Biklen (in Moleong, 2007, p. 248) are efforts made clearly working with data, organizing, sorting it out, synthesizing it, finding and finding patterns, determining what is important and learning, and deciding what can be shared with other parties.

In qualitative data analysis, not always the data obtained related to research. The researcher will reduce the data obtained so that the researcher does not describe all findings in the field, but only partially, the data related to research problems. The sorted data is then analyzed. Data that has been sorted and related to the research and the results of the analysis will be shared with other parties.

Informant. The informants in this study play a role in providing information and understanding for researchers about the object of research more comprehensively through in-depth interviews. In-depth interviews in this study were carried out to parties related to research problems, including virtual office parties, tax academics, tax practitioners, and the Directorate General of Taxes Deducting Tax Collections.

\section{Results and Discussion}

\section{Analysis of Virtual Office Based on the Rent Concept}

\section{Those who Tie Themselves $U p$}

In the first element, in a lease there are at least parties that rent out and parties that are leased from the goods. Both parties bind themselves in the lease agreement. Simply put, that in a virtual office there are parties that are mutually binding, namely virtual office providers and virtual office users. How to bind yourself between the two parties is usually done by making an agreement. A lease agreement is a form of legal relationship between the owner or provider of a virtual office and a virtual office user. Agreements between providers and virtual office users are commonplace in this business practice as agreements regarding leased goods. This is because the lease agreement between the virtual office provider and virtual office users is the basis of the contractual relationship between the two parties.

\section{Delivery of Goods to be Enjoyed by Others}

The other element contained in the lease is to hand over the goods by the party who rents out to the party that is leased to then enjoy the goods. The goods submitted do not mean giving ownership rights but only for their usefulness. Goods in this case are narrower notions of objects. Objects have a broad understanding because their abstract nature includes tangible and intangible objects. The goods themselves are part of the meaning of things, so according to Frieda Husni Hasbullah (2002) goods have concrete and tangible properties, which can be seen and touched. Hofmann and De Berger said that what can be an object in the lease agreement is a bodied item (lichamelijke zaken), which is bodied in this case the same as tangible objects (Hasbullah, 2002).

An address is a location identity attached to a place or building. A place or building can be considered as an item considering that the item is an object that has concrete and tangible 
properties, which can be seen and touched as well as the concept of goods described by Frieda Husni Hasbullah. In the context of the virtual office itself, the address seems to indicate the existence of a business, so as if it were at the address or in other words the listed virtual office address is an identity. Therefore, an address cannot be said as an item because the address is only an identity or a location marker and is not physical. This is because in a rental, goods are one of the principal elements of rent as stated by Subekti (1995).

The second element of the lease is not fulfilled by the virtual office because the service provided by the virtual office to the user is address leasing, reception services, call forwarding, and correspondence. The lease element in a virtual office for delivery of goods to be enjoyed by other parties is fulfilled if there is a business lounge usage or the use of a meeting room by a virtual office user. In some virtual office services such as virtual office services provided by Regus and $A B C$ virtual office there is the use of business lounges or workstations and meeting rooms even though in a limited time. The use of business lounges or workstations and meeting rooms can be said to be the use of space by virtual office users. The business lounge or workstation and meeting room can be said to be a room that is tangible, visible and touchable. This is like the concept of goods according to Frieda Husni Hasbullah and, Hofmann and De Berger that goods are tangible and can be the object of lease agreements.

\section{Rental Prices}

Rental prices as a form of reciprocity for handing over goods to be enjoyed by others are the third element of leasing. In each leasing lease there is a reciprocal form of money as the rental price of the leased object. Rental prices are not only in the form of money but can also be in the form of goods or services (Subekti, 1995, p. 41). This rental price is something that must be paid to the party that rents out the goods that have been rented. The rental price is one of the main elements in the lease so that in the agreement this must be written as clearly as possible. In virtual office rental prices are usually also listed on the website of the virtual office provider accompanied by services tailored to their respective prices. For example, in Regus virtual office service, the rental price for a month is Rp. 496,000, - with facilities such as the use of business addresses, mail handling services, business lounge usage, and telephone numbers with reception services. While the $\mathrm{ABC}$ virtual office set rental prices in the range of five hundred fifty thousand rupiahs to one million rupiah per month. This depends on what services users choose because in the $\mathrm{ABC}$ virtual office there are two packages, Bronze and Silver. The only difference is the number of time limits for using the room with a longer time limit on the Silver package. Meanwhile, other services are not different from Regus's virtual office services.

\section{Specific Time}

The last element is a certain time. The specified time is the period of time for the use of goods to be enjoyed. The period of time depends on the length of usage desired by the tenant and also based on the agreement of both parties. In some virtual office usually, the rental time is given a minimum limit by the party who rents out, for example in the Regus virtual office, the minimum rental time is one month. Meanwhile in the virtual office ABC the minimum rental time is one year followed by direct payments a year. The difference in rental time in all virtual offices is regulated based on the provisions of each virtual office provider.

Based on a review of the element of rent, it is actually a virtual office that has services for using business lounges, meeting or meeting rooms, or other parts of the room that have fulfilled the elements of rent. Virtual office which in its service does not use the room does not meet the third element, that is, the other party does not get pleasure from an item. Goods in this case are 
tangible, visible and touchable. Virtual office services that do not provide access to use business lounges or meeting rooms, therefore the virtual office services do not fulfil the concept of goods because they only provide pleasure for intangible goods such as addresses, and services.

\section{Virtual Office Analysis Based on Service Concepts}

The service is basically a form of economic activity by service providers to service users which activities are intangible and do not result in any ownership. Unlike leases that deliver goods to be enjoyed by other parties, in the service there is no delivery of goods but instead submits something intangible to be enjoyed together at the time of production and there is added value to the intangible thing. This can be exemplified in vehicle repair services, in that service the mechanic does not provide goods in the form of cars or the like to service users but provides vehicle repair services which are not physically shaped, so satisfaction of service users will arise.

Virtual office in practice in Indonesia at least generally provides leasing services for addresses, call forwarding and correspondence services. Some virtual offices also provide services for using business lounges or meeting rooms, within the time limit specified by service providers in the services they offer. As discussed earlier in the conceptual review of rent, a virtual office that provides services for using business lounges or meeting rooms within the prescribed time limit fulfil the concept of goods, which is something tangible, visible and touchable. Therefore, the element of rent that delivers goods to be enjoyed by other parties can be fulfilled because the items in the virtual office can be in the form of business lounges or meeting rooms.

However, for virtual offices that do not provide services using business lounges or meeting rooms, it cannot be categorized as a form of rent. This is because the services provided do not meet the criteria for goods. Therefore, it is necessary to review also in terms of service concepts and service characteristics that were triggered by Kotler and Keller. The characteristics of services are at least 4 characteristics, namely intangibility, inseparability, perishability, and variability.

\section{Intangibility}

The first element is intangible or intangibility. The intangible character of service is that it cannot be seen, touched, or felt by the sense of smell. This is like the concept of service itself, which is a form of economic activity that gives up something that is not intangible. When linked to a virtual office that provides services such as address leasing, reception services, call forwarding, and correspondence services, it can be said that these services are intangibles provided by virtual office providers. This is because virtual office users do not accept tangible things that can be felt, seen and touched but only receive intangible services that can only be felt in the form of satisfaction by their users, whether the service is good or bad. As stated by Lupiyoadi related to the characteristics of this service, users will have difficulty evaluating services before buying or using the service. Likewise, with a virtual office because it provides services that are intangible and not in the form of goods, the prospective user cannot determine which virtual office to use is good or bad. Prospective users can only evaluate via feedback or comments from previous virtual office users.

\section{Cannot be Separated (Inseparability)}

The second element of service is inseparability. The purpose of this inseparability service element is the inseparability of production and consumption of services provided to service users. These occur at the same time and are usually represented in the form of direct contact. 
This shows that there is a moment of truth or something tangible in providing services. Apart from direct contact, it can also be done through telephone or mail communication.

Virtual office from the perspective of inseparability services can be reflected in the services it provides. This is reflected in the reception services, picking up and forwarding telephone calls, or correspondence. As an element of inseparability that production of a service and consumption of a service cannot be separated because it occurs at the same time. Virtual office users will feel or consume services in virtual office services for example when a client or business associate from a virtual office user calls a virtual office and the receptionist will carry out his duties to pick up and forward the phone to the virtual office user. This is as stated by Lupiyoadi that inseparability is an element of service where production and consumption occur simultaneously. When the receptionist serves a virtual office, user related to administrative needs or when the receptionist picks up and forwards the telephone to a virtual office user, at that time there has been a production service by the receptionist as part of the virtual office provider as well as the consumption of services by virtual office users. Unlike the production of goods that can be stored, in services when production occurs, the services are directly consumed by other parties and cannot be stored for services that have been produced. Consumers also have, feel, and are involved in the production of services. As when the receptionist picked up and forwarded the telephone to the virtual office user as a consumer. If there is no incoming call, there will be no production of these services to consumers so that it can be said that consumers, in this case virtual office users, must feel and be involved when the receptionist as the service provider produces his services.

\section{Perishability}

The third element, perishability, is still related to the previous element because this element explains that services cannot be stored when services are not used at one time. Referring to the previous element that the production and consumption of services is carried out at the same time, so that if the service is not used then the service cannot be used for the future. This is like in a virtual office, for services provided if it is not used, the service cannot be used in the future and cannot be stored. Unused services will pass. When the receptionist or virtual office operator does not receive any calls, e-mails or letters, there will be no production of services to the virtual office user and the time that is not used to produce services will pass. When on one day nothing can be served, the service cannot be stored. Virtual office users will receive services if there is a call, e-mail or letter into the virtual office to be forwarded to the virtual office user. Virtual office users usually have agreed to use a virtual office for a certain period of time, when there is one day that does not occur the production of virtual office services, then one day cannot be added beyond the agreed period.

\section{Variability}

The use of virtual offices will lead to reciprocity to virtual office providers in the form of rental prices or rewards for services. The rental price or service fee in the concept of income is an additional economic capability for the virtual office provider. This is due to the additional economic capabilities received or obtained by taxpayers who can be used for consumption or other things. The use of income becomes unimportant, so the income is used for anything, all are taxed (Mansury, 1999). This virtual office income is usually received by virtual office providers from Indonesia due to the large number of virtual office users are MSMEs and startups originating from Indonesia, as well as the concept of income in the tax itself that additional economics can come from Indonesia or anywhere from worldwide income. 


\begin{tabular}{|c|c|c|c|c|}
\hline $\begin{array}{c}\text { Income Tax } \\
\text { Object }\end{array}$ & Tax Base & $\begin{array}{c}\text { Income } \\
\text { Tax } \\
\text { Rates }\end{array}$ & Tax Paid* & Information \\
\hline $\begin{array}{l}\text { Article } 4 \text { paragraph } \\
\text { (2) Income Tax } \\
\text { Law on Land and / } \\
\text { or Building Leases }\end{array}$ & $\begin{array}{l}\text { Gross amount of all } \\
\text { payments for } \\
\text { leasing land and / or } \\
\text { buildings }\end{array}$ & $10 \%$ & $\begin{array}{ll}\operatorname{Rp} 550.000 & x \\
10 \% & = \\
\operatorname{Rp} 55.000 & \end{array}$ & $\begin{array}{l}\text { There is use of } \\
\text { meeting rooms }\end{array}$ \\
\hline $\begin{array}{l}\text { Article } 23 \text { of the } \\
\text { Income Tax Law on } \\
\text { Management } \\
\text { Services }\end{array}$ & $\begin{array}{l}\text { The gross amount } \\
\text { of all compensation } \\
\text { for management } \\
\text { services does not } \\
\text { include Value } \\
\text { Added Tax }\end{array}$ & $2 \%$ & $\begin{array}{ll}\operatorname{Rp} 550.000 & x \\
2 \% & = \\
\operatorname{Rp} 11.000 & \end{array}$ & $\begin{array}{l}\text { There is no use } \\
\text { of the meeting } \\
\text { rooms }\end{array}$ \\
\hline
\end{tabular}

Table 1: Imposition of Income Tax on The Virtual Office

In addition, the virtual office income is either referred to as the rental price or service fee, but the substance is income, which is an additional economic capability for the virtual office provider.

So, it can be seen from the income concept that virtual office income fulfil the concept and as in Income Tax that the income tax object is income. Therefore, the next is the determination of the income tax object referred to as rent or service. This is due to differences in treatment in Income Taxes.

Imposition of Income Tax in the form of a lease on a virtual office is imposed if in the virtual office service there is something tangible to be enjoyed by virtual office users. The treatment as a lease can be fulfilled if the service includes services for using a meeting room or business lounge. As the concept of goods is something tangible, visible, and touchable. Use of the meeting room is included in a sense of part of the room. A partial understanding of this room as described in the Elucidation of Article 2 paragraph (1) of Government Regulation Number 34 of 2017 concerning Income Tax on Income from Land and / or Building Rental (hereinafter referred to as PP 34 of 2017), namely the area both inside and outside the building which is part of the building, such as the building's terrace, rooms inside a house, pavilion, swimming pool, and so on. Buildings regulated in PP 34 of 2017 are the results of engineering construction that is attached to land and / or water. This shows that the building has the properties of goods, namely tangible, can be seen, and touched because it is arranged with a construction work system which in its construction consists of various kinds of building materials such as brick, iron, steel, and so on.

Imposition of Income Tax on the lease of land and / or building itself is regulated in Article 4 paragraph (2) of the Income Tax Law. Virtual offices that fulfil the form of land leases and / or buildings under taxation rules can be subject to Income Tax Article 4 paragraph (2). Even though it only uses a portion of the building, the virtual office is still included in the land and / or building rental object subject to Income Tax Article 4 paragraph (2). This is because in Article 2 paragraph (1) PP 34 of 2017 confirms that the object of Income Tax Article 4 paragraph (2) is not only for all buildings but also part of buildings. The imposition of Income 
Tax on the lease of land and / or buildings in Article 4 paragraph (2) of the Income Tax Law is subject to a tariff of $10 \%$. This Income Tax Imposition is final, which means it cannot be credited in the calculation of Corporate Income Tax. The tax base is based on the gross amount of all paid to the virtual office provider, including the use of space and services used by virtual office users. Related services and other things given in the virtual office can be considered as a service charge.

While the imposition of income tax on services if the virtual office does not provide room use services. virtual office that does not use space is more appropriate in the service category. This is also in accordance with the elements of service where there is a delivery of something intangible, inseparable between production and consumption, easily damaged or not durable, and varied. Indonesia's Income Tax Rules currently do not regulate virtual office services so that if a virtual office is charged for services it is more appropriate to be categorized as management services. Director General of Taxes Circular Letter Number SE-35 / PJ / 2010 concerning Definition of Leases and Other Income Regarding the Use of Assets, Technical Services, Management Services, and Consultant Services as referred to in Article 23 Paragraph (1) Income Tax Law (hereinafter -referred to as SE 35 Years 2010) defines management services in the Income Tax Law as "providing services by participating directly in the management or management". Participate directly in this sense as in a virtual office that the provision of services is carried out directly by the customer service or the virtual office receptionist. Picking up and forwarding the telephone, as well as correspondence is done directly by the virtual office receptionist as the operator. Income Tax Imposition on management services provided by virtual office providers is an object of Income Tax Article 23. Income from management services needs to be tax deductible at $2 \%$ of gross amount excluding Value Added Tax as stipulated in Article 23 Paragraph (1) of Income Tax Law and the implementing regulations for PMK 141 of 2015 and SE 35 of 2010. The gross amount is the total amount of income in name and in whatever form paid, provided to be paid, or the payment has expired, not including:

- payment of salaries, wages, honoraria, allowances, and other payments as compensation in respect of work paid by the Taxpayer providing labor to workers who do work, based on contracts with service users;

- payment to service providers for the procurement / purchase of goods or materials related to services provided;

- $\quad$ payments to third parties paid through service providers, related to services provided by service providers; and / or payment to the service provider which is a reimbursement of the fees that have been paid by the service provider to a third party in order to provide the related services.

\section{Conclusions}

Virtual office that provides services in the form of leasing business addresses, reception services, call forwarding services, mail handling services, and the use of meeting rooms, workstations, or business lounges. Based on the rental concept, the Virtual office meets the concept of rent because there is a space that is recognized as an item, that is, as something tangible. However, a virtual office that does not provide room use services but only leases address and services is classified as a service. 
Virtual office in its use there is a rental price or service fee provided by the user to the virtual office provider. Reciprocity is income for virtual office providers in terms of the concept of income. Imposition of Income Tax in a virtual office can be treated as land and / or building rent or services. This depends on the presence or absence of room use in the services provided to virtual office users. Final Income Tax Imposition is imposed on a virtual office that has space usage services such as meeting rooms, workstations, or business lounges. Income Tax applied is Income Tax Article 4 paragraph (2) at a rate of $10 \%$ of the gross amount paid on land and / or building rent. Income Tax Imposition in a virtual office that does not provide space use services is treated as management services because of direct involvement in the form of activities carried out by the receptionist. The Income Tax applied is Article 23 Income Tax at a rate of $2 \%$ of the gross amount in return for management services.

Based on these conclusions, the suggestions that can be given regarding the income tax treatment of the virtual office are the Indonesian virtual office association, the virtual office provider, and the government needs to conduct discussions and standardization regarding the available virtual office services so that there are similarities in treatment virtual office as a service or rent. The discussion and standardization is to provide equalization of virtual office understanding to all parties, both private providers of virtual office and government as policy makers so that virtual office definitions are formed in general and can avoid differences in virtual office treatment. The definition of virtual office that has not been regulated in taxation regulations can lead to disagreements in treating income tax as a service or rent. Therefore, the Directorate General of Taxes needs to conduct studies and coordination with all relevant parties to establish implementing regulations that clearly and clearly define and regulate virtual offices in taxation.

\section{References}

Harahap, Y. (1991). Segi-Segi Hukum Perjanjian. Bandung: Alumni.

Hasbullah, F. H. (2002). Hukum Kebendaan Perdata: Hak-Hak yang Memberi Kenikmatan Jilid 1. Jakarta: Ind-Hill Co.

Infiniti. (2018). "Virtual Office". Rerieved from infiniti.id/virtual-office

Lupiyoadi, R. (2013). Manajemen Pemasaran Jasa. Jakarta: Salemba Empat.

Mansury, R. (1999). Pajak Penghasilan Atas Transaksi-Transaksi Khusus. Tangerang: YP4.

Moleong, L. J. (2007). Metodologi Penelitian Kualitatif. Bandung: Remaja Rosdakarya Offset. Nasution, M. N. (2004). Manajemen Jasa Terpadu. Bogor: Ghalia Indonesia.

Neuman, W. L. (2014). Social Research Methods: Qualitative and Quantitative Approaches (Seventh). United States of America: Pearson Education Limited.

Nirwana. (2006). Service Marketing Strategy. Malang: Dioma.

Piri, H. G. (2013). Kualitas Pelayanan Jasa Pengaruhnya Terhadap Loyalitas Pelanggan Pada Steiner Salon Manado. EMBA, 1(4), 506.

Projodikoro, W. (1981). Hukum Perdata tentang Persetujuan Tertentu. Bandung: Alumni.

Subekti, R. (1995). Aneka Perjanjian. Bandung: PT. Citra Aditya Bakti.

Subekti, R. (2005). Hukum Perjanjian. Jakarta: PT. Intermasa.

Sugiyono. (2012). Metode Penelitian Kuantitatif, Kualitatif, dan R\&D. Bandung: Alfabeta. 